\title{
Journal of Soil and Water Science
}

\section{Evaluation of Heavy Metal Contamination in Surface and Ground Water in Maiganga, Gombe State, Nigeria}

\author{
Babangida Hammani ${ }^{1 *}$, Mohamed Salih Osman ${ }^{2}$, Khalid Abdallah Mohamm
Danladi ${ }^{4}$ and Adanu Emmanuel $O^{1}$
${ }^{1}$ Department of Agricultural Education, Federal College of Education (Technical), Nigeria \\ ${ }^{2}$ Department of Horticultural Science, Faculty of Agriculture \& Natural Resources, University of \\ Bakht Al-Ruda, Sudan \\ ${ }^{3}$ Department of Crop Science, Faculty of Agriculture \& Natural Resources, University of Bakht Al- \\ Ruda, Sudan \\ ${ }^{4}$ Department of Soil Science Faculty of Agriculture, Federal University, Nigeria
}

\begin{abstract}
This study examines the levels of heavy metal contamination of farmland water from Maiganga Community in Akko local government area of Gombe state, Nigeria. Maiganga is a community famous for its deposit of coal which has attracted miners to the area. Water samples were collected from 10 different farming locations in the community. They were collected from Boreholes, Wells (groundwater) and Open water (surface water). The samples were digested and analysed for the presence of heavy metals (Lead, Cobalt, Nickel, Cadmium, Copper and Chromium) using the Buck Scientific 205 Atomic Absorption Spectrophotometer. The results showed that there is the presence of Lead, Nickel, Cobalt and Cadmium with no significant difference $(P<0.05)$ to the source and location of water collected. The range and average values of Lead were 1.35-2.07 mg/L and $1.75 \mathrm{mg} / \mathrm{L}$; Cobalt were 1.60-3.53 mg/L and $2.72 \mathrm{mg} / \mathrm{L}$; Nickel were 1.32-3.27 $\mathrm{mg} / \mathrm{L}$ and $2.37 \mathrm{mg} / \mathrm{L}$; and Cadmium were $0.15-0.31 \mathrm{mg} / \mathrm{L}$ and $0.251 \mathrm{mg} / \mathrm{L}$ respectively. However, there were no traces of Cupper and Chromium in the samples. It can be concluded that the water samples from the various sources were highly contaminated with heavy metals. Again, most of the heavy metal values were above the permissible limits set by WWF, SON \& WHO guidelines. There is the need for regular monitoring for heavy metals in order to prevent the accumulation in plants.
\end{abstract}

\section{Keywords}

Heavy metals, Water, Contamination, Maiganga, Nigeria

\section{Introduction}

Water is the vital resource which influences the human life. Generally, water found in two forms of natural sources surface water (lakes, ponds, rivers, streams etc.) and ground water (bore holes and well water) [1]. Both the surface and groundwater pollution due to toxic heavy metals has been a main concern for environment currently. Water is toxic and very harmful even at a trace level of heavy metals present in it $[2,3]$.

Heavy metal contamination in the environment has been occurring for centuries, and in the previous decade it has increased rapidly due to technological developments [4]. Human activities that result in the discharge of heavy metals into the environment include industrial processes, mining, automobile emissions, agricultural, wastewater discharge, and urban runoff $[5,6]$, while the natural sources of heavy metals may include weathering and dissolution of minerals, parent rocks, and soils $[7,8]$. The heavy metal contaminations are vital due to their potential toxicity for human being and environments $[9,10]$. Some of the heavy metals such as $\mathrm{Cu}$, $\mathrm{Fe}, \mathrm{Ni}$ and $\mathrm{Zn}$ are essential micronutrients for animals and

*Corresponding author: Babangida Hammani, Department of Agricultural Education, Federal College of Education (Technical), P.M.B. 60 Gombe, Gombe State, Nigeria, Tel: +234-802897-7817

Accepted: December 27, 2020

Published online: December 29, 2020

Citation: Hammani B, Osman MS, Mohammed KA, et al. (2021) Evaluation of Heavy Metal Contamination in Surface and Ground Water in Maiganga, Gombe State, Nigeria. J Soil Water Sci 5(2):218-222

Copyright: (C) 2021 Hammani B, et al. This is an open-access article distributed under the terms of the Creative Commons Attribution License, which permits unrestricted use, distribution, and reproduction in any medium, provided the original author and source are credited. 


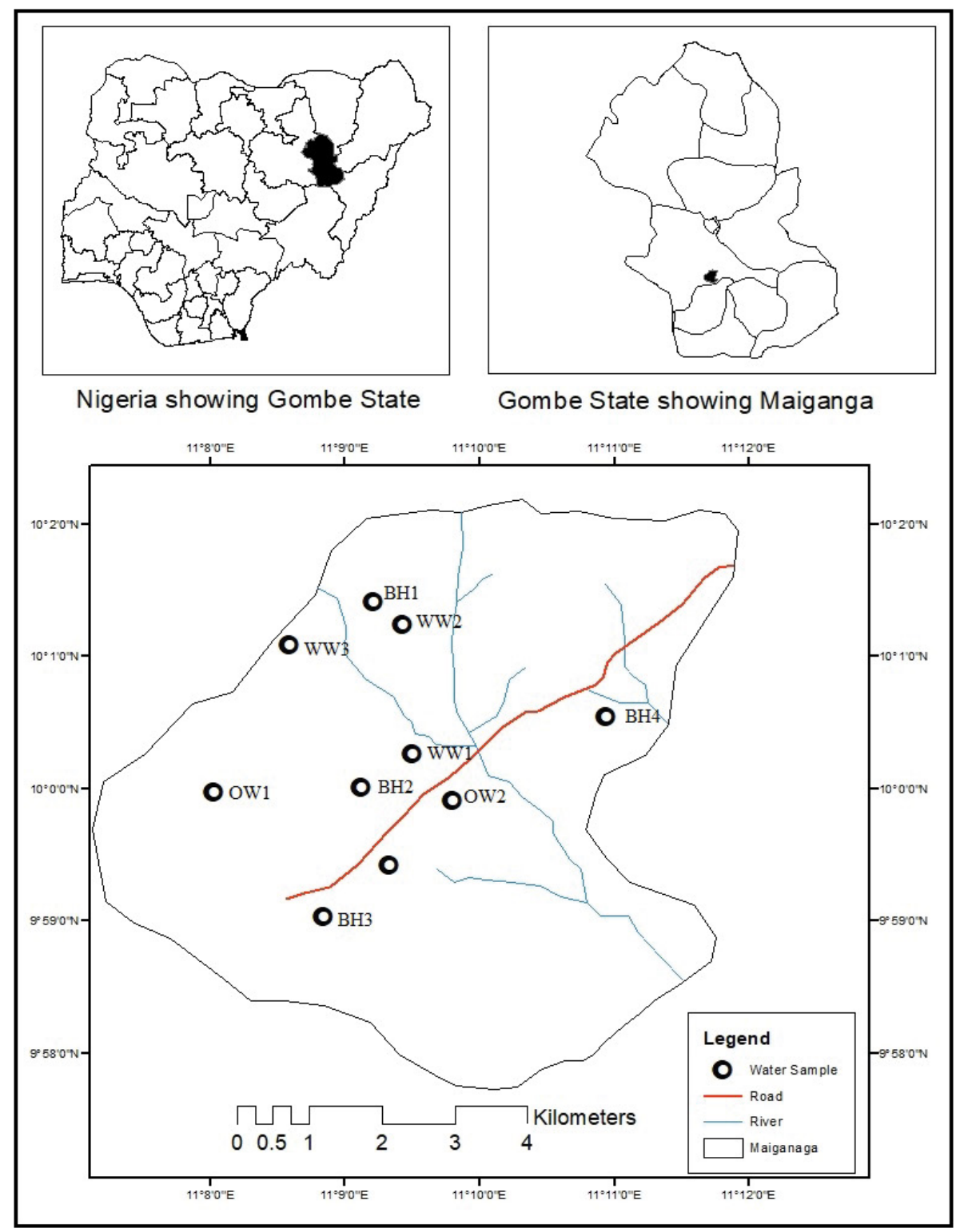

Figure 1: Map of Maiganga.

plants but are dangerous at high levels, whereas $\mathrm{Cd}, \mathrm{Cr}, \mathrm{Pb}$ and Co have no known physiological functions but are harmful at certain limits [11,12]. Furthermore, $\mathrm{Cr}, \mathrm{Cd}$ and $\mathrm{Ni}$ are carcinogenic, while $\mathrm{Pb}$ may cause neurological impairment and central nervous system malfunctioning [13].

The objective of this study was to evaluate the level of heavy metal contamination in surface and ground water in Maiganga, Gombe State, Nigeria.

\section{Materials and Methods}

\section{Area of the study}

The research was conducted in Maiganga village $\left(09^{\circ} 18^{\prime} \mathrm{N}\right.$, and $11^{\circ} 59^{\prime} \mathrm{E}$ ) which located in Akko local government area of Gombe state, Nigeria (Figure 1). It is a community that is famous for its deposit of coal which has attracted miners and companies to the area. It covers a total area of about 48.16 $\mathrm{km}^{2}$. Geographically the study area is developed on basement complex rock. The population of Maiganga village is about 3,520 persons. The area lies or falls within the tropical continental type of climate characterized by well-marked wet and dry season. The mean annual rainfall ranges between 850-1000 $\mathrm{mm}^{3}$ and the raining season last between 5 to 6 months, while the mean temperature is relatively high for most part of the year.

\section{Sample collection}

Water samples were collected from 3 different water sources; they included: Open water (surface water), borehole waters and well water (ground water). Ten samples were collected which include 5 borehole $(\mathrm{BH})$, two open water (OW) and three well water (WW). These represent the major sources of water supply for the people in Maiganga village. Sampling was collected in July 2018. Samples were collected using $500 \mathrm{ml}$ plastic bottles. These bottles were pre-soaked using $10 \% \mathrm{HCl}$ over 12 hours before rinsing with 


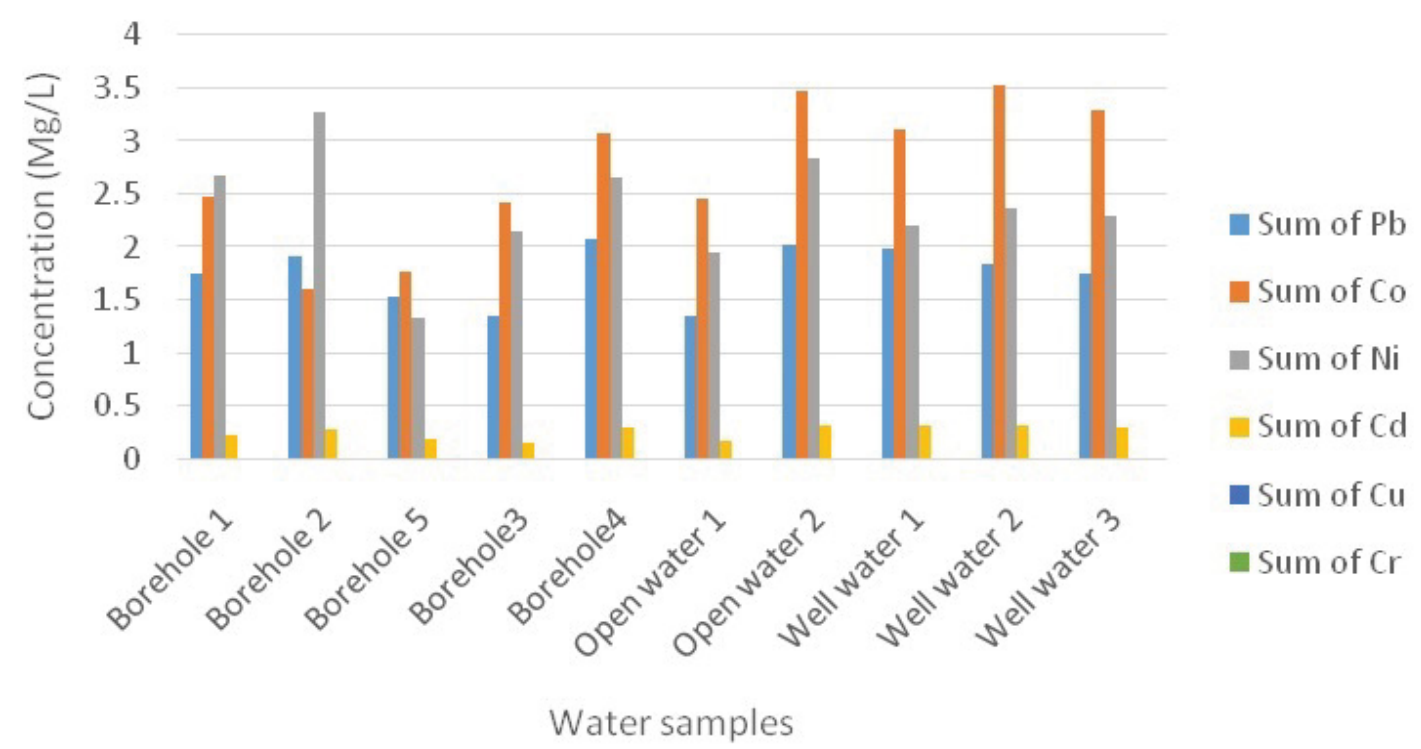

Figure 2: Mean concentrations of Heavy metals in waters samples from Maiganga.

Table 1: Mean concentrations of heavy metals in water samples in Maiganga village.

\begin{tabular}{|l|l|l|l|l|l|l|l|}
\hline Heavy Metal & $\begin{array}{l}\text { Mean } \\
\text { Value }\end{array}$ & Std Deviation & Min. Value & Max. Value & Acceptable & Highest Perm. & $\begin{array}{l}\text { CPCB (for inland } \\
\text { surface water) }\end{array}$ \\
\hline $\mathrm{PH}$ & 6.9 & 0.24 & 6.6 & 7.4 & 6.0 & 8.0 & \\
\hline $\mathrm{Pb}(\mathrm{mg} / \mathrm{L})$ & 1.75 & 0.26 & 1.35 & 2.07 & 0.01 & $\mathrm{NR}^{\mathrm{a}}$ & 0.1 \\
\hline $\mathrm{Co}(\mathrm{mg} / \mathrm{L})$ & 2.72 & 0.66 & 1.60 & 3.53 & $\mathrm{~N} / \mathrm{A}$ & N/A & \\
\hline $\mathrm{Ni}(\mathrm{mg} / \mathrm{L})$ & 2.37 & 0.51 & 1.32 & 2.83 & 0.02 & NR $^{\mathrm{a}}$ & 3 \\
\hline $\mathrm{Cd}(\mathrm{mg} / \mathrm{L})$ & 0.25 & 0.063 & 0.15 & 0.31 & 0.003 & NR $^{\mathrm{a}}$ & 2 \\
\hline $\mathrm{Cu}(\mathrm{mg} / \mathrm{L})$ & 0 & 0 & 0 & 0 & 0.05 & 1.5 & 3 \\
\hline $\mathrm{Cr}(\mathrm{mg} / \mathrm{L})$ & 0 & 0 & 0 & 0 & 0.05 & NR $^{\mathrm{a}}$ & 2 \\
\hline
\end{tabular}

N/A: Not Available; ${ }^{a} N R:$ Not Relevant

distilled water. Collected water was preserved by 2 drops of concentrated $\mathrm{HNO}_{3}$ to each sample collected before storage under $4{ }^{\circ} \mathrm{C}$ right until analysis. The analysis was done in the laboratory unit; Department of Biochemistry Gombe State University PMB127, Nigeria.

\section{Analytical procedure}

The $\mathrm{pH}$ of all samples was measured by $(\mathrm{pH}$ meter 781 Metrohm Model). The concentrations of heavy metals ( $\mathrm{Pb}$, $\mathrm{Co} \mathrm{Ni}, \mathrm{Cd} \mathrm{Cu}$ and $\mathrm{Cr}$ ) concentration were measured using the Buck Scientific 205 Atomic Absorption Spectrophotometer as described by [14].

All samples were collected and analysed in three replicates and the average results and standard deviation were used to represent the data. The data were analyzed using statistical software program by SPSS 21.

\section{Results and Discussion}

The mean concentrations of heavy metals in water samples in Maiganga village are shown in Table 1. While heavy metal concentrations of water in Maiganga village from different sampled source are in Table 2. Figure 2 showed mean concentrations of heavy metals in waters samples from Maiganga. Permissible limits of some heavy metals in water in Wastewater Forum (WWF), World Health Organisation (WHO) and Standard Organization of Nigeria (SON) are shown in Table 3.

The $\mathrm{pH}$ of all water samples ranged between 6.6 to 7.4 which is within the allowed WHO limit (6.5-8.5). This finding is in line with the findings of [15] who worked in groundwater of Northwest Bank in Palestine found the $\mathrm{pH}$ of water samples within the US Environmental protection Agency limits.

\section{Lead $(\mathrm{Pb})$}

The mean concentration of lead in water samples at Maiganga ranged from 1.35 to $2.07 \mathrm{mg} / \mathrm{L}$. The lowest mean concentration of lead was obtained at $\mathrm{BH} 3$ and OW1 and the highest concentration at $\mathrm{BH} 4$. There were no significant differences in lead concentrations between the surface water and ground water. In the present study all the samples are exceeds the max concentration according to WHO [16], Wastewater Forum (WWF) [17] and Standard Organization of Nigeria (SON) [18]. The high concentrations of the lead in water samples may be due to mining activities in Maiganga 
Citation: Hammani B, Osman MS, Mohammed KA, et al. (2021) Evaluation of Heavy Metal Contamination in Surface and Ground Water in Maiganga, Gombe State, Nigeria. J Soil Water Sci 5(2):218-222

Table 2: Heavy metal concentrations of water in Maiganga village from different sampled sources.

\begin{tabular}{|l|l|l|l|l|l|l|l|l|l|l|}
\hline $\begin{array}{l}\text { Heavy } \\
\text { Metal }\end{array}$ & $\begin{array}{l}\text { BH 1 } \\
(\mathrm{mg} / \mathrm{L})\end{array}$ & $\begin{array}{l}\text { BH 2 } \\
(\mathrm{mg} / \mathrm{L})\end{array}$ & $\begin{array}{l}\text { BH 3 } \\
(\mathrm{mg} / \mathrm{L})\end{array}$ & $\begin{array}{l}\text { BH 4 } \\
(\mathrm{mg} / \mathrm{L})\end{array}$ & $\begin{array}{l}\text { BH 5 } \\
(\mathrm{mg} / \mathrm{L})\end{array}$ & $\begin{array}{l}\text { OW 1 } \\
(\mathrm{mg} / \mathrm{L})\end{array}$ & $\begin{array}{l}\text { OW 2 } \\
\text { (mg/L) }\end{array}$ & $\begin{array}{l}\text { WW 1 } \\
\text { (mg/L) }\end{array}$ & $\begin{array}{l}\text { WW 2 } \\
(\mathrm{mg} / \mathrm{L})\end{array}$ & $\begin{array}{l}\text { WW 3 } \\
(\mathrm{mg} / \mathrm{L})\end{array}$ \\
\hline $\mathrm{Pb}$ & 1.75 & 1.91 & 1.35 & 2.07 & 1.52 & 1.35 & 2.01 & 1.99 & 1.83 & 1.75 \\
\hline $\mathrm{Co}$ & 2.47 & 1.603 & 2.42 & 3.06 & 1.77 & 2.457 & 3.48 & 3.10 & 3.53 & 3.29 \\
\hline $\mathrm{Ni}$ & 2.67 & 3.27 & 2.15 & 2.65 & 1.32 & 1.95 & 2.83 & 2.20 & 2.37 & 2.29 \\
\hline $\mathrm{Cd}$ & 0.22 & 0.28 & 0.15 & 0.29 & 0.18 & 0.17 & 0.31 & 0.31 & 0.31 & 0.29 \\
\hline $\mathrm{Cu}$ & 0 & 0 & 0 & 0 & 0 & 0 & 0 & 0 & 0 & 0 \\
\hline $\mathrm{Cr}$ & 0 & 0 & 0 & 0 & 0 & 0 & 0 & 0 & 0 & 0 \\
\hline
\end{tabular}

Table 3: Permissible limits of some heavy metals in water in Wastewater Forum, WHO and Standard Organization of Nigeria.

\begin{tabular}{|l|l|l|l|}
\hline Standard & (WWF) & (WHO) & (SON) \\
\cline { 1 - 3 } $\mathrm{Mg} / \mathrm{L}$ & & & \\
\hline Lead, $\mathrm{Pb}$ & 0.1 & 0.01 & 0.01 \\
\hline Cobalt, Co & & 0.005 & \\
\hline Nickel, Ni & 0.2 & 0.07 & 0.02 \\
\hline Chromium, Cr & 0.01 & 0.05 & 0.05 \\
\hline Copper, Cu & 0.2 & 2 & 1 \\
\hline Cadmium, Cd & 0.01 & 0.003 & 0.003 \\
\hline
\end{tabular}

Source: WWF: 2007; WHO: 2008 and SON: 2016

village. This finding is in line with the findings of Nnabo [19] who reported that the groundwater was naturally enriched in heavy metals, but previous mining activities resulted in highly polluted and toxic groundwater at the shrouded area of the mines by $\mathrm{Pb}$.

Lead is widely known to be toxic even at low concentration especially in young children. Its ingestion has been associated with deleterious health effects, including disorder of central nervous system [20].

\section{Cobalt (Co)}

The minimum and maximum concentration of cobalt was 1.60 and $3.53 \mathrm{mg} / \mathrm{L}$, respectively. These amounts were more than the standard limit $(0.00553 \mathrm{mg} / \mathrm{L})$ in WHO [16]. The lowest concentrations of $\mathrm{Co}$ found in $\mathrm{BH} 2$ while the highest concentration in WW2. The highest Co concentration was obtained in ground water samples. These results are in agreement with those reported by Orosun, et al. [21] who reported that the concentration of $\mathrm{Cr}$ in different sources of water in mining and smelting area in Ajaokuta in Nigeria were too exceeds compared to the WHO permitted limit in drinking water. The long-term exposure to $\mathrm{Cr}$ can cause liver damage, kidney circulatory and nerve tissues, as well as skin irritation $[22,23]$.

\section{Nickel (Ni)}

The mean of Ni concentration in Maiganga water samples was $2.37 \mathrm{mg} / \mathrm{L}$. The highest concentrations of $\mathrm{Ni}$ found at $\mathrm{BH} 2$ $(3.27 \mathrm{mg} / \mathrm{L})$, and the lowest concentration found at BH5 (1.32 $\mathrm{mg} / \mathrm{L})$. The recorded concentrations of $\mathrm{Ni}$ in different sources of water above the maximum permissible limit of WHO
(2011), WWF (2007) and SON (2016) for water quality (Table 3). Nickel is a dietary element required for many organisms, but increase concentration leads many hazards effect like torpogenic and carcinogenic to mammals [1].

\section{Cadmium (Cd)}

The mean concentrations of Cadmium in water samples ranged from $0.15 \mathrm{mg} / \mathrm{L}$ to $0.31 \mathrm{mg} / \mathrm{L}$; with $\mathrm{BH} 3$ recorded the lowest concentration in water and WW1 recorded the highest concentration. The average of Cd was $0.25 \mathrm{mg} / \mathrm{L}$. The results of Cadmium concentration in water is above the maximum permissible limit for the maximum permissible limit of WHO (2011), WWF (2007) and SON (2016). According to Seema, et al. [15], the presence of Cadmium in drinking water may be required by the body in small amounts but can also be toxic in large doses. The cadmium may occur in water naturally or as a contaminant from sewage sludge, fertilizers, polluted groundwater or mining and industrial effluents [24].

\section{Copper ( $\mathrm{Cu}$ ) and Chromium ( $\mathrm{Cr}$ )}

Copper and Chromium were not detected in all water samples in ground and surface water.

\section{Conclusion}

Results of this study revealed that Lead, Cobalt, Nickel, and Cadmium concentration in the ground surface water in Maiganga village are higher than the WHO (2006), WWF (2007) and SON (2016). Copper and Chromium were not detected in all samples. Sources of the heavy metals in the waters are mainly due to human activities and might be attributed to the mining activities in the Maiganga area. Water treatment should be implemented to circumvent toxicity effects associated with the presence of heavy metals in domestic using of water.

\section{References}

1. Tadiboyina R, Ptsrk R (2016) Trace analysis of heavy metals in ground waters of vijayawada industrial area. International Journal of Environmental \& Science Education 11: 3215-3229.

2. Marschner $H$ (1983) General introduction to the mineral nutrition of plants. Encyclopaedia of plant physiology. New Series 15: 5-60.

3. Chhatwal GR, Mehra MC, Satake M, et al. (1992) Encyclopaedia of environmental pollution and its control. Anmol Publications 6: 41-154. 
4. Vrhovnik P, Arrebola JP, Serafimovski T, et al. (2013) Potentially toxic contamination of sediments, water and two animal species in Lake Kalimanci, FYR Macedonia: Relevance to human health. Environ Pollut 180: 92-100.

5. Wei B, Yang L (2010) A review of heavy metal contaminations in urban soils, urban road dusts and agricultural soils from China. Microchem J 94: 99-107.

6. Mohiuddin KM, Ogawa Y, Zakir HM, et al. (2011) Heavy metals contamination in water and sediments of an urban river in a developing country. Int J Environ Sci Tech 8: 723-736.

7. Adamu Cl, Nganje TN, Edet A (2015) Heavy metal contamination and health risk assessment associated with abandoned barite mines in Cross River State, southeastern Nigeria. Environ Nanotechnol Monit Manag 3: 10-21.

8. Purushothaman P, Chakrapani GJ (2007) Heavy metals fractionation in Ganga River sediments, India. Environ Monit Assess 132: 475-489.

9. Lee CL, Li XD, Zhang G, et al. (2007) Heavy metals and Pb isotopic composition of aerosols in urban and suburban areas of Hong Kong and Guangzhou, South China. Evidence of the long-range transport of air contaminants. Atmos Environ 41: 432-447.

10. Vinodhini R, Narayanan M (2008) Bioaccumulation of heavy metals in organs of fresh water fish Cyprinus carpio (Common carp). Int J Environ Sci Tech 5: 179-182.

11. Nadal M, Schuhmacher M, Domingo JL (2004) Metal pollution of soils and vegetation in an area with petrochemical industry. Sci Total Environ 321: 59-69.

12. Aktar MW, Paramasivam M, Ganguly M, et al. (2010) Assessment and occurrence of various heavy metals in surface water of Ganga river around Kolkata: A study for toxicity and ecological impact. Environ Monit Assess 160: 207-213.

13. Okegye JI, Gajere JN (2015) Assessment of heavy metal contamination in surface and ground water resources around udege mbeki mining district, north-central Nigeria. J Geol Geophys 4: 203.

14. Barbeş L, Bărbulescu A, Rădulescu C, et al. (2014) Determination of heavy metals in leaves and bark of populus nigra I by atomic absorption spectrometry. Romanian Reports in Physics 66: 877 886.
15. Seema S, Swati L, Jeena H, et al. (2011) Heavy metals contamination in water and their harzardous effect on Human Health-A review. Int J Curr Microbiol App Sci 3: 239-246.

16. World Health Organization (2008) Guideline for drinking water quality. ( $4^{\text {th }}$ edn), WHO Geneva, Switzerland.

17. Wastewater Forum (2007) Report on natural surface water classification criteria irrigation water quality guidelines for Pakistan Febuary.

18. Standard Organization of Nigeria (2016) Nigerian standard for drinking water quality. Standards Organization of Nigeria, Abuja, Nigeria.

19. Nnabo Paulinus N (2015) Assessment of heavy metal contamination of water sources from enyigba $\mathrm{Pb}-\mathrm{Zn}$ District, Southeastern Nigeria. International Journal of Scientific \& Technology Research 4: 187-197.

20. Malassa H, Hadidoun M, Al-Khatib M, et al. (2014) Assessment of groundwater pollution with heavy metals in Northwest Bank/ Palestine by ICP-MS. Journal of Environmental Protection 5: 5459.

21. Orosun M M, Tchokossa P, Nwankwo LI, et al. (2016) Assessment of heavy metal pollution in drinking water due to mining and smelting activities in ajaokuta, Nigeria. Nigerian Journal of Technological Development 13: 31-39.

22. Tseng CH, Chong CK, Tseng CP (2003) Long-term arsenic exposure and ischemic heart disease in arseniasis-hyperendemic villages in Taiwan. Toxicol Lett 137: 15-21.

23. Smith AH, Hopenhayn-Rich C, Bates MN, et al. (1992) Cancer risks from arsenic in drinking water. Environ Health Perspect 97: 259-267.

24. Houng KH, Lee DY (1998) Comparisons of linear and nonlinear Langmuir and Freundlich curve- $f$ it in the study of $\mathrm{Cu}, \mathrm{Cd}$ and $\mathrm{Pb}$ adsorption on Taiwan soils. J Soil Sci 163: 115-121.

DOI: $10.36959 / 624 / 447$

Copyright: (c) 2021 Hammani B, et al. This is an open-access article distributed under the terms of the Creative Commons Attribution License, which permits unrestricted use, distribution, and reproduction in any medium, provided the original author and source are credited. 